\title{
Economic Community of West African State's (ECOWAS) Controversy: Wither a Need for Single Currency by 2021 ?
}

\author{
Opue Job Agba ${ }^{1^{*}}$--- Ifeoma Stella Madueme ${ }^{2}$ \\ ${ }^{1,2}$ University of Nigeria, Nsukka, Nigeria. \\ 'Email:ngajiz4@unical.edu.ng. \\ 'Email:madueme@unn.edu.ng.
}

\begin{abstract}
The business cycles in the West African Monetary Zone (WAMZ) as well as West African Economic and Monetary Union (WAEMU) using real GDP growth within 1980-2019, detrended by Hodrick-Prescott filters were analyzed. The Pearson correlation analysis on the computed z-scores was employed to examine the level of synchronization of business cycles, the level of symmetry in macroeconomic policies and the level of symmetry in trade flows. It was evident that business cycles synchronization was on the whole increasing, but with higher intensity within WAEMU region than within WAMZ region where only Ghana-Guinea, Ghana-Nigeria, Guinea-Gambia as well as Guinea-Nigeria as pairs were significantly synchronized. Symmetry in macroeconomic policies was on the whole minimal within ECOWAS region. The flow of trade however within ECOWAS region was asymmetric between Cote d'Ivoire and other WAEMU countries and between Nigeria and other WAMZ countries, but was symmetric between other ECOWAS countries, indicating that these economies rely more on transaction with other developed economies. The empirical results provided a direction for countries with synchronized business cycles such as Ghana, Guinea, Gambia and Nigeria to consider proceeding in the creation of the second West African monetary union (SWAMU) while also creating an enabling environment for other countries within WAMZ to join in due course. The study recommended among others that any country under WAEMU without strong similarities with other countries as pairs should disengage from WAEMU. On the converse, countries with strong similarities as pairs should unilaterally realign their exchange rate.
\end{abstract}

Keywords: Trade-flows, Macroeconomic policy, Business cycles, Synchronization, Symmetry.

JEL Classification: C32; C51; E32; F15; F42; F53.

Licensed: This work is licensed under a Creative Commons Attribution 4.o License.

Funding: This study received no specific financial support.

Competing Interests: The authors declare that they have no competing interests.

Acknowledgement: Authors sincerely wish to thank all the lecturers of the Department of Economics, University of Nigeria, Nsukka for painstakingly proofreading this work and making valuable suggestions. May the almighty God grant you all your hearts' desire.

\section{Background to the Study}

The year 2020 had been slated for the commencement of the second West African monetary union and the conditions for being part of the body was succinctly endorsed as the ECOWAS macroeconomic convergence criteria. These criteria, which are simply similarity targets, have been violated several times, resulting to subsequent postponements of the commencement dates for the creation of the monetary union. As reflected in appendix A, no country was able to satisfy all the primary convergence criteria between 2001 and 2005, hence, the postponement of the launch of the monetary union to December 2009. Between 2006 and 2008, Gambia satisfied all the four criteria, while Nigeria met all the four criteria in 2006 and 2007. In 2009, only Liberia 
satisfied all the four criteria following its accession to the WAMZ Programme. Thus, the launch date for the monetary union was again shifted to on or before January 1, 2015, and consequently to January, 2020 and it was still not realistic. While some countries of the zone were negatively affected by civil conflicts, the situation was compounded by severe terms to trade experienced by many countries in the last few years. A major militating factor was expansionary fiscal policies, which tended to weaken relatively tight monetary policies pursued by the sub-region's central banks. The poor state of infrastructure was also unconducive to investments and economic growth (Sanusi, 2003). The upsurge of Covid-19 pandemic further drowned most economies in West Africa and heightened barriers on the creation of a monetary union in 2020.

For WAEMU region, the current estimates and projections from IMF (2018) shows that on overall fiscal balance to GDP ratio, eight countries violated it, while on tax revenue to GDP ratio, seven countries violated it in 2016. Some purported hindrances to successful implementation of the second West African monetary union included: lack of political will and commitment; non-similarity in the flow of trade and in the level of fluctuations of business cycles; and non-similarity in macroeconomic policy coordination and harmonization between WAMZ and WAEMU (Franken., Fort, \& Parrado, 2011; Sanusi, 2003; Tarawalie, Ahortor, Adenekan, \& Conte10, 2012). Following the non-achievements of the convergence criteria, there is need to therefore investigate further on the various levels attained so far in these similarities targets and examine if these levels could synchronize regional business cycles given that a sufficient degree of business cycles synchronization is a prerequisite for the creation of a monetary union.

However, previous research findings are of the view that the stronger the level of synchronization of business cycles between countries of the same region the greater the need for monetary cum economic integration (Calderón, Chong, \& Stein, 2002; Fiess, 2005; Kappel, 2015). But statistical trends of AFDB (2018) reveals that the dignity of West African states has been grossly eroded in recent past despite her numerous resources. Recessions and booms were experienced at diverse intervals: the recession of Gambia was in 2014, that of Liberia in 2016, Sierra Leone in 2015, Cote d'Ivoire in 2011, Guinea Bissau in 2012, Mali in 2012 and Nigeria, the so-called giant of Africa experienced her recession in 2016. The gross domestic product growth from AFDB (2018) in Figure 1 and Figure 2 captures this for both WAMZ and WAEMU between 2010 and 2017. It is indicative of the wide disparities in business cycles fluctuations within each region and offer clues of asymmetries in business cycles. It is therefore not certain if the level of synchronization of business cycles between pair of countries within WAMZ and WAEMU could be adequate for the formation of a second West African monetary union.

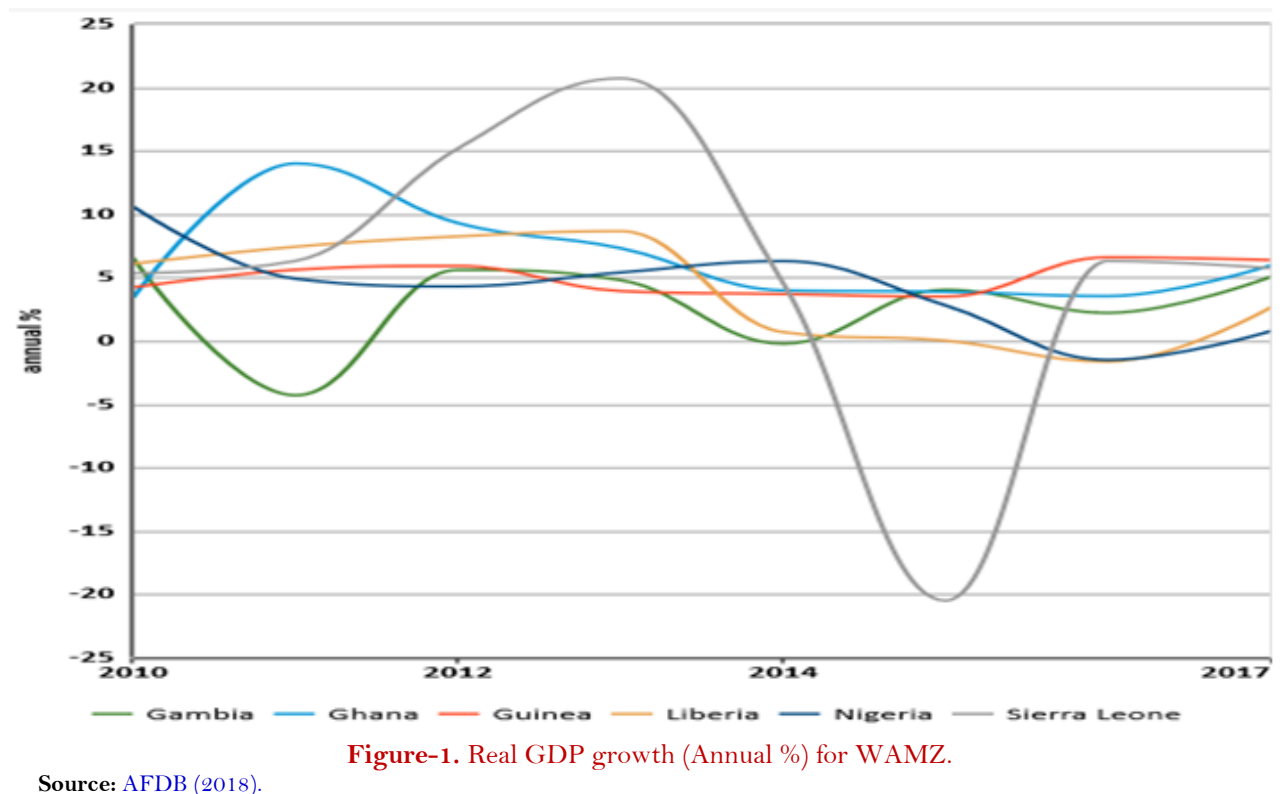

Another important objectives of integration attempts most especially in West Africa, is to work towards symmetry in trade flows (Maruping, 2005) because asymmetry in trade flows may adversely affect macroeconomic policies (e.g., monetary and fiscal policies as well as exchange rates) and hinder business cycles synchronization (Akin, 2006; Baxter. \& Kouparitsas, 2005; Bordo \& Helbling, 2003; Chang, 2011; Darvas \& Szapáry, 2004; De Haan, Inklaar, \& Jong-A-Pin, 2005; Fidrmuc, 2001; Frankel \& Rose, 1998; Grigoli, 2011 ; Jules-Armand, 2007; Juvenal \& Monteiro, 2012; Kose, Prasad, \& Terrones, 2003; Mendoza, 1991; Mendoza., 1995; Nzimande \& Ngalawa, 2017; Pundit, 2011; Rana, 2007a; Rana., 2007b; Shin \& Wang, 2004). 


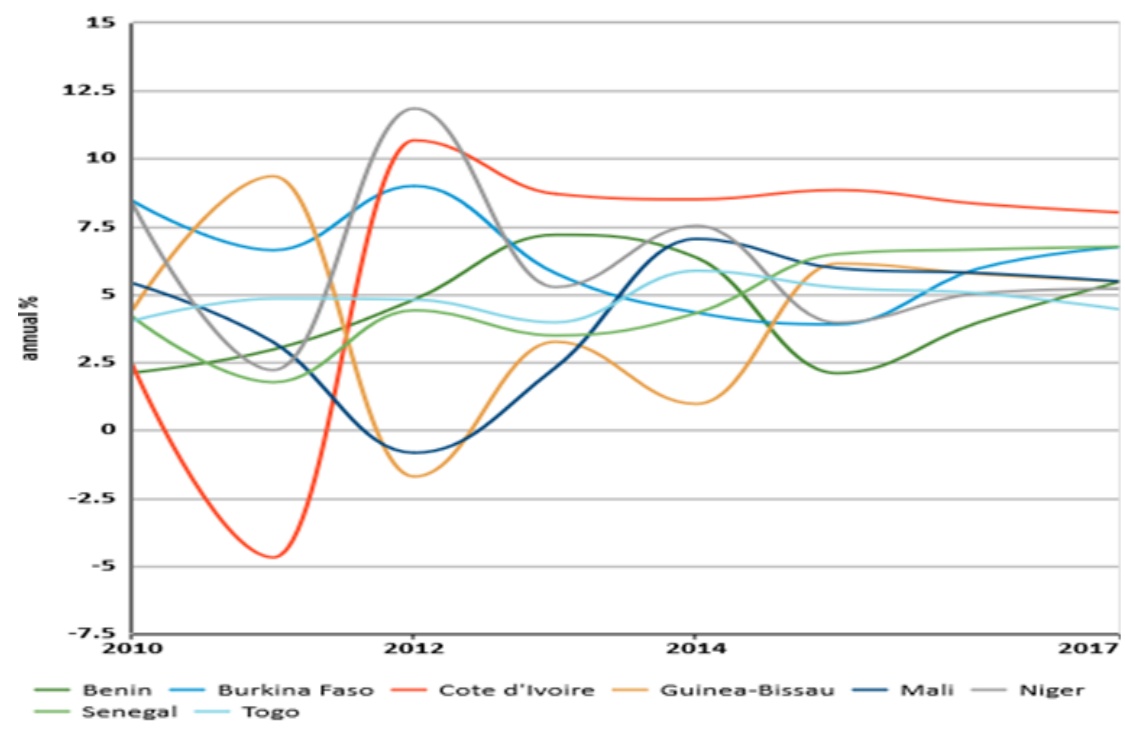

Source: AFDB (2018).

Figure-2. Real GDP growth (Annual \%) for WAEMU.

Nevertheless, the various similarity targets of the ECOWAS macroeconomic convergence criteria were silent on regional trade, which was duly emphasized in the optimum currency area theory. This stipulates that countries within the same region must intensely trade with each other. The trade statistics from UNCTADstat (2018) reveals that: countries within ECOWAS region traded intensely with countries outside the region and minimally with countries within the same region; the flow of trade between 2005 down to 2017 as shown in Figure 3 and 4 were all in deficit, that is, countries within ECOWAS region imported more than they exported; and the flow of trade from Nigeria alone was two times that of other ECOWAS countries put together. These disparities in trade trends offer clues of asymmetries in the flow of trade within West African states. Language and multiple currencies most especially within the WAMZ region are a major factor impeding the flow of trade within these economies. Another factor is the undue restrictions in currency convertibility as well as production patterns. Most countries within West Africa only export raw materials such as crude oil and agricultural products like cocoa, oil palms, groundnuts, etc., to countries outside Africa and thereafter import finished goods that are not within the reach of countries within West African subregions. These trends in the pattern of trade flows could result in strong asymmetries in the level of trade flows and could inhibit the level of synchronization of business cycles within West African regions.

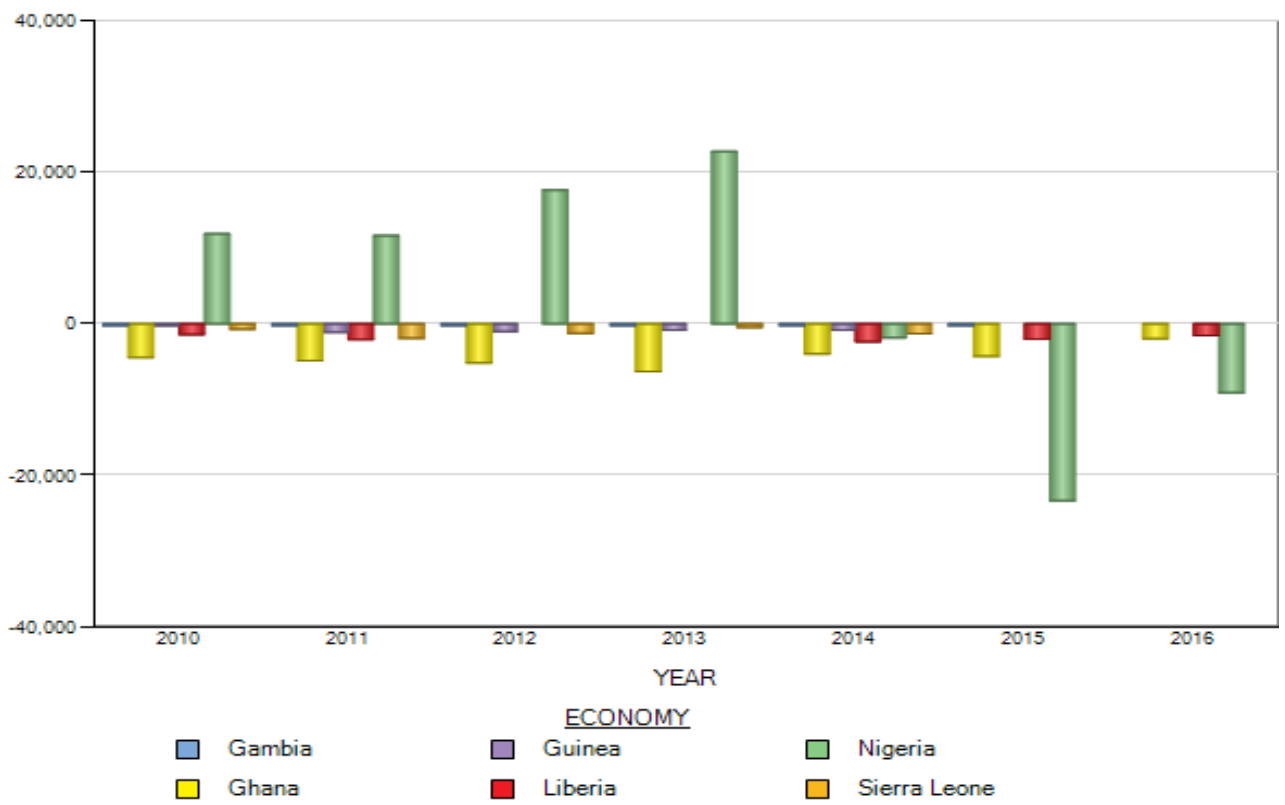

Figure-3. Total trade balance in goods and services (US Dollars at current prices in millions) for WAMZ. Source: UNCTADstat (2018). 


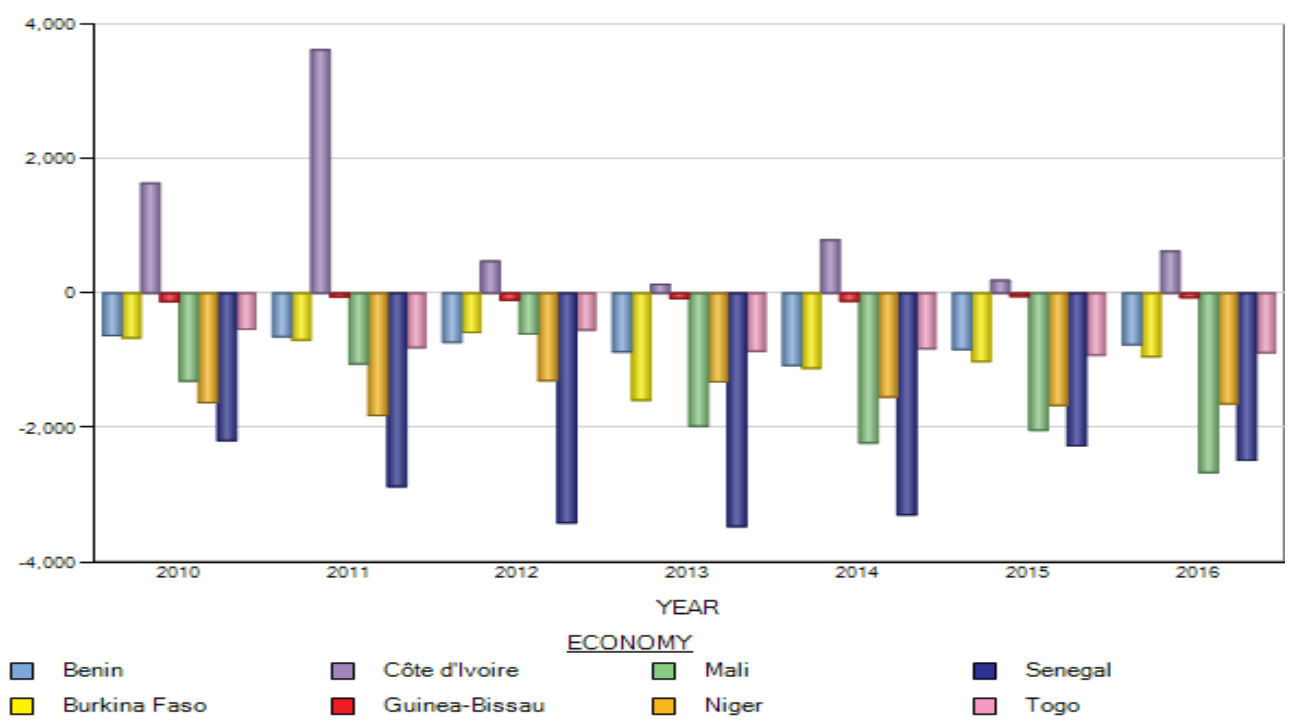

Figure-4. Total trade balance in goods and services (US Dollars at current prices in millions) for WAEMU. Source: UNCTADstat (2018).

Events during the last decade have revealed significant defects in the fiscal and monetary operations in West Africa. It is anticipated that as one of the primary macroeconomic convergence criteria the ratio of fiscal balance to gross domestic product growth must be less than or equal to $4 \%$. The optimum currency area criteria also prescribed from a political standpoint that countries in an integration area must be ready to share the burden by compensating each other whenever there are emerging distortions or shocks. However, all countries within WAMZ and WAEMU had wide disparities in fiscal balance (as percentage of GDP) between 2015 and 2017 (AFDB, 2018; World Bank, 2018). These figures were all in deficits and clearly indicate that these economies survive on borrowing and must borrow to sustain each other during crises. It does not in any way offer clues of adequacy in their compensatory capacity to sustain a steady growth and hence ensure an adequate level of synchronization of business cycles within West Africa.

Consequently, this study in its quest on regional integration in West Africa attempts to unravel the level of symmetry in trade flows, optimal macroeconomic policy and business cycles synchronization in West Africa.

\subsection{Research Objectives}

The broad objective of this study is to examine trade flows, optimal macroeconomic policy and business cycles synchronization in West Africa. The specific objectives are as follows:

(1) To evaluate the level of symmetry in trade flows and the level of symmetry in macroeconomic policies between pairs of countries in West Africa.

(2) To evaluate the level of synchronization of business cycles between pairs of countries within West Africa.

\section{Empirical Literature Review}

The empirical literatures expound on the effects of trade-integration/bilateral-trade/trade-intensity and macroeconomic policy on business cycles synchronization in Europe, Asia and America. In Africa, and above all West Africa, research work in this area is still rare. Most of the findings resulted from different methodologies such as the HP filters, the BP filters, the Generalized Method of Moment, the VAR, SVAR, FAVAR and DSGE models as the case may be. Most of the studies came to a conclusion that increase in tradeintegration/bilateral-trade/trade-intensity increases business cycles synchronization (Akin, 2006; Bordo \& Helbling, 2003; Chang, 2011; Darvas \& Szapáry, 2004; De Haan et al., 2005; Fidrmuc, 2001; Grigoli, 2011 ; Jules-Armand, 2007; Juvenal \& Monteiro, 2012; Mendoza, 1991; Mendoza., 1995; Pundit, 2011)). In the same vein, Calderón et al. (2002) were of the view that a positive relationship between trade intensity and cycle correlation could potentially be due to both variables being explained by a third factor, namely, the formation of a currency union. And that the impact of trade intensity on cycle correlation is smaller the greater the production structure asymmetries between countries. However, for Artis and Zhang (1999) increased monetary integration was positively related to business cycles synchronization, while Krugman (1993) opined that integration was likely to support specialization according to the comparative advantage.

However, Kumakura (2005) deviated from the point of view of the traditional OCA theory given the speed of globalization among the Asia-Pacific countries by arguing that a monetary union enhances trade and business cycle co-movements among its member countries sufficiently as to obviate the need for national monetary policy. According to his result, although trade was relevant to the business cycles of individual countries, the main determinant of their international correlations was not the geographical structure of their 
trade but what they produce and export more specifically and the extent to which their output and exports were concentrated on electronic products. His work was one of the first of the kinds that proffered clues on similarities in trade patterns as a determinant factor for the synchronization of business cycles.

Jules-Armand (2007) argued that the impact of African bilateral trade on BCS was positive and robust. He tested for the 53 African countries over the 1975-2004 periods the hypothesis suggesting that monetary integration adds force to bilateral trade intensity which in turn, improves conditions for the practice of common monetary policy throughout business cycles synchronization. In addition to macroeconomic convergence criteria, the promotion of bilateral trade by dropping tariff, non-tariff and infrastructures barriers would accelerate the synchronization of African business cycles and facilitate African monetary integration. More trade thus brings African business cycles closer together and could add force to various projects of monetary integration in progress. Finally, he opined that those results did not take into account other possible controls mentioned in recent papers such as similarity of trade and of productive structure, and that such data were very difficult to collate for African countries. So far, his paper had remained an optimistic view on African monetary integration. It provided some insights on the fact that African MUs could be self-validating through bilateral trade but the aspect of the effects of macroeconomic policies, that is, monetary and fiscal policies on business cycles synchronization were not taken into consideration. His work did not also consider the aspect of the effects of the level of symmetry in trade flows on business cycles synchronization.

Coleman (2011) contributed to the discussion on the long-term sustainability of the embryonic second monetary union in Africa, the West African Monetary Zone (WAMZ). He analyzed the level of economic and monetary integration in West Africa by analyzing the degree of growth cycle synchronization between the five candidate countries over the past thirty years. His empirical approach improves on the standard Pearson Correlation between trend and cyclical components of GDP by analyzing a measure of co-movement at higher frequencies between computed z-scores for all possible pairings of the candidate countries. His results indicated a lack of a consistent pattern of synchronized growth cycles, which raises concerns about the economic sustainability of the WAMZ, as it implies that members may face significant stabilization costs. No investigation was made on issues in trade flows and macroeconomic policies holistically.

On the effect of macroeconomic policies, most research works reviewed revealed that the convergence of macroeconomic policies such as fiscal and monetary policies were systematically linked to business cycles synchronization (Böwer \& Guillemineau, 2006; Crespo-Cuaresma, Pfaffermayr, Fernández-Amador, \& Keppel, 2010; Jidoud, 2012)). However, of all the works reviewed, including the trade theories, none emphasized or addressed the issue of industrialization of UDCs and LDCs in West Africa through introduction of cyclical thrifts scheme and incentives from reserves/savings from regional countries, to stimulate investment and production, to cushion anticipated distortions/shocks before, during and after monetary integration for symmetry in trade flows and business cycles synchronization

This work intends to cover this gap by analyzing the level of symmetry in trade flows, level of symmetry in macroeconomic policies and the level of synchronization of business cycles between pairs of countries within WAMZ and WAEMU separately with the aid of Pearson correlation coefficient on computed z-scores.

\section{Theoretical Framework}

The theoretical framework of this study anchors on the theory of Optimum Currency Areas (OCA) to show the relevance of establishing a monetary union in West Africa as a developing nation. 1961 was the year Mundell published a revolutionary paper in which he first developed the concept of OCA. Important contributions to expound the theory were later made by McKinnon (1963) and Kenen (1969). In general, the decision to join a currency area involves the abandonment of an independent national monetary policy to follow a unified one. This might involve the creation of a new single currency by a new independent central bank or the fixity of the national mutual exchange rates. In the latter case, a common reserve will be needed for countries to supplement their external positions vis-à-vis other member countries (Cohen, 1992). If the currency area chooses to peg its unified currency (single or multiple) to a key currency (such as US dollar or euro), it abandons the area's monetary independence for the sake of the key currency's country. Towards this decision, the OCA theory emphasizes on economic integration, that is, the synchronization of business cycles of regional countries as the main aim to join a currency area.

For regional countries to be economically integrated, that is to synchronize their business cycles, the following conditions were prescribed: there has to be free flows of goods and services within the region, i.e., production and export are widely diversified and of similar structure between countries and countries are very open to trade and trade heavily with each other, hence, there should be symmetry in trade flows; there has to be free flows of financial capital (assets) and physical capital; free flows of workers/labour i.e., there exist immigration and emigration; likewise, countries must agree to compensate each other for adverse shocks, currency union member countries must share a wide consensus on the way to deal with shocks and when the common monetary policy gives rise to conflicts of national interests, the countries that form a currency area need to accept the costs in the name of a common destiny (Baldwin \& Wyplosz, 2009; Kenen, 1969; McKinnon, 1963; Mundell, 1961). 
3.1. Definition of Variables

(i) Business Cycle Synchronization (BS)

To measure this variable, the time series correlation coefficient between de-trended Real GDPs growth of country i and j is used as follows (Akin, 2006; Calderón et al., 2002; Shin \& Wang, 2004):

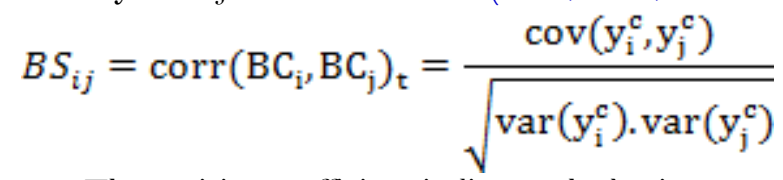

The positive coefficient indicates the business cycle synchronization between two counties i and j while its negative sign is an indication of non-synchronization. However, to avoid correlation coefficient to be bounded in the [-1: 1] interval, the correlation was computed over 3-year interval with non-overlapping window, so that the error term in a regression model with those correlation coefficients as dependent variable would be normally distributed. This is aimed at making the inference on estimated results to be unbiased. This also conforms to studies on duration of business cycles: Burns and Mitchell (1946) define the duration of a business cycle for the United States of America between a minimum of 16 and 22 months and a maximum of 100 and 106 months. For the United Kingdom the values lie between minimal 16 and 22 months and maximal 135 and 141 months. Baxter and King (1999) refer to Burns and Mitchell, but declare the minimum and maximum duration of a business cycle to be 6 and 32 quarters respectively. Where $\operatorname{corr}\left(\mathrm{y}_{\mathrm{i}}^{\mathrm{c}}, \mathrm{y}_{\mathrm{j}}^{\mathrm{c}}\right)$ is the pair-wise correlation coefficient of the cyclical components of real GDP growth of country i and country j. $y_{i}^{c}$ represents de-trended real GDP growth, i.e., the i cyclical component of real output y for country $i$, while $y_{j}^{\mathrm{c}}$ is the $j$ cyclical component of real output $y$ for country $\mathrm{j}$ and $\mathrm{t}$ is the time span. The measure of the cycle will be obtained by Hodrick-Prescott (HP) filtering of real output data, where $\lambda=100$ since annual frequencies in the data was used. The values for each variable would be computed over the period 1980 to 2017.

\subsection{Trade Flows Similarity Index (TF)}

Regarding the independent variables, to measure the level of symmetry in trade flows, a correlation coefficient of external trade balance in goods and services of two countries are calculated. For this, the trade flow in each country in the given time period is calculated first and the correlation coefficient between them is then estimated as follows:

\section{$T F_{i j t}=\operatorname{corr}\left(\mathrm{TF}_{\mathrm{i}}, \mathrm{TF}_{\mathrm{j}}\right)_{\mathrm{t}}$}

The correlation was computed over 3-year interval with non-overlapping window, so that the error term in a regression models would be normally distributed.

\section{(iii) Monetary Policy Similarity Index (MP)}

The first measure of macroeconomic policy is the similarity in monetary policy. A correlation coefficient of broad money supply growth of two countries is calculated based on the study of Shin and Wang (2004). For this, the growth rate of broad money supply in each country in the given time period is calculated first and the correlation coefficient between money growths is then estimated thus:$$
M P_{i j t}=\operatorname{corr}\left(\mathrm{MP}_{\mathrm{i}}, \mathrm{MP}_{\mathrm{j}}\right)_{\mathrm{t}}
$$

The correlation was computed over 3-year interval with non-overlapping window, so that the error term in a regression models would be normally distributed.

\section{(iv) Fiscal Policy Similarity Index (FP)}

The second measure of macroeconomic policy is the similarity in fiscal policy. Fiscal shocks have strong, persistent and positive impact on output. Several papers in the literature have measured similarities in fiscal policy, using correlation coefficient or mean absolute difference of budget deficit to GDP ratios of country i and $\mathrm{j}$ for period $\mathrm{t}$. This paper measures similarity index of fiscal policies by looking at the correlation of central government fiscal balance as a percentage of GDP for country $\mathrm{i}$ and $\mathrm{j}$ :

$$
\mathrm{FP}_{\mathrm{ij}}=\operatorname{corr}\left(F P_{i t}, F P_{j t}\right)
$$

The correlation was computed over 3-year interval with non-overlapping window as well.

\subsection{Sources of Data}

The dataset used for this research contains yearly observations dating from 1980 to 2019 due to lack of availability of monthly and quarterly series. The missing observations in the available series were interpolated with the aid of TRAMO/SEATS environment following Gomez and Maravall (1996). Data were sourced from World Development Indicator (WDI) of the World Bank (2018), United Nations Conference on Trade and Development (UNCTADstat) (2018), World Economic Outlook, country database and AFDB (2018). 


\section{Result of Pearson Correlation Analysis for West African Monetary Zone (WAMZ)}

Table-1. Pearson correlation analysis for West African Monetary Zone (WAMZ).

\begin{tabular}{|c|c|c|c|c|c|}
\hline \multirow{2}{*}{ Country pairs } & \multicolumn{4}{|c|}{ Variables } & \multirow{2}{*}{$\begin{array}{c}\text { Synchronization/ } \\
\text { Symmetry level }\end{array}$} \\
\hline & BS & TF & MP & FP & \\
\hline Ghana-Guinea & $0.500^{*}$ & $0.465 * *$ & 0.053 & 0.015 & $++\mathrm{OO}$ \\
\hline Ghana-Gambia & 0.389 & $0.864^{*}$ & 0.360 & 0.250 & $\mathrm{O}+\mathrm{OO}$ \\
\hline Ghana-Liberia & -0.227 & $0.818^{*}$ & -0.094 & 0.166 & $\mathrm{O}+\mathrm{OO}$ \\
\hline Ghana-Nigeria & $0.508^{*}$ & $-0.505^{*}$ & $0.529 * *$ & 0.313 & $+-+\mathrm{O}$ \\
\hline Ghana-Sierra Leone & -0.020 & $0.455^{* *}$ & 0.246 & 0.409 & $\mathrm{O}+\mathrm{OO}$ \\
\hline Guinea-Gambia & $0.591^{*}$ & 0.362 & 0.340 & 0.120 & $+\mathrm{OOO}$ \\
\hline Guinea-Liberia & -0.350 & $0.748^{*}$ & 0.332 & $0.474^{* * *}$ & $\mathrm{O}+\mathrm{O}+$ \\
\hline Guinea-Nigeria & $0.499^{* *}$ & $-0.810^{*}$ & -0.061 & 0.144 & $+-0 \mathrm{O}$ \\
\hline Guinea-Sierra Leone & 0.272 & $0.555^{*}$ & 0.171 & 0.108 & $\mathrm{O}+\mathrm{OO}$ \\
\hline Gambia-Liberia & -0.323 & $0.791^{*}$ & -0.045 & 0.154 & $\mathrm{O}+\mathrm{OO}$ \\
\hline Gambia-Nigeria & 0.367 & $-0.524^{*}$ & 0.135 & 0.371 & $\mathrm{O}-\mathrm{OO}$ \\
\hline Gambia-Sierra Leone & 0.080 & $0.449^{* *}$ & 0.052 & 0.144 & $\mathrm{O}+\mathrm{OO}$ \\
\hline Liberia-Nigeria & -0.230 & $-0.760^{*}$ & 0.403 & $0.672^{*}$ & $\mathrm{O}-\mathrm{O}+$ \\
\hline Liberia-Sierra Leone & -0.270 & $0.660^{*}$ & 0.083 & 0.223 & $\mathrm{O}+\mathrm{OO}$ \\
\hline Nigeria-Sierra Leone & 0.124 & $-0.702^{*}$ & 0.056 & 0.128 & $\mathrm{O}-\mathrm{OO}$ \\
\hline
\end{tabular}

Note: $(+)$ synchronous/symmetric; (-) asynchronous/asymmetric; (0) insignificant; $\left({ }^{*}\right) 1$ percent level of significance; $\left({ }^{* *}\right) 5$ percent level of significance; BS Business cycles; TF - Trade flows; MP - Monetary policy; FP - Fiscal policy

\subsection{Interpretation of the Result on Business Cycles for WAMZ}

As indicated in Table 1 only four pairs of countries' business cycles were significantly synchronous and these includes Ghana-Guinea, Ghana-Nigeria, Guinea-Gambia as well as Guinea-Nigeria with correlation coefficient of (0.50), (0.51), (0.59) and (0.50) respectively. The other countries' correlation coefficients were all statistically insignificant and this goes to support the views of Coleman (2011) that raised concern on a lack of a consistent pattern of synchronized business cycles, which could be inadequate for the economic sustainability of the WAMZ, as it implies that members may face significant stabilization costs.

\subsection{Interpretation of the Result on Trade Flows For WAMZ}

As further shown in Table 1, trade flows between pairs of countries within WAMZ were all significantly symmetric with correlation coefficients ranging between (0.47) to (0.86) except in the case of countries' pairs with Nigeria where all values of correlation coefficients were significantly asymmetric. The correlation coefficients on trade flows between Ghana-Nigeria, Guinea-Nigeria, Gambia-Nigeria, Liberia-Nigeria and Nigeria-Sierra Leone as countries' pairs were (-0.51), (-0.81), (-0.52), (-0.76) and (-0.70) respectively.

The significant level of asymmetry in trade flows between Nigeria and all other countries within WAMZ could firstly be attributed to the fact that these regions are developing economies and are also import dependent. Their only source of export is raw materials which are exported to developed economies. Secondly, Nigeria alone accounts for two times the volume of exports/imports to and from countries outside WAMZ. This supports the findings of Mendoza (1991); Mendoza. (1995) that goods produced within by developing economies are not competitive enough to satisfy the needs of the region. These economies need to intensify production by dwelling on their areas of expertise and high proficiency so as to satisfy the needs of their economies. Another reason advanced for this is language disparities which is also a threat to trade. ECOWAS launched a Trade Liberalization Scheme (ETLS) in 1990, and planned to move to a Customs Union with a Common External Tariff (CET) by 2008. Despite some implementation challenges, a Free Trade Area (FTA) has been achieved, with tariffs on products from member states abolished within the community. However, complex procedures regarding rules-of-origin, discordant customs systems and procedures, difficulties with insurance and bond guarantees for transit cargo, and other non-tariff barriers (NTB), including roadblocks and demands for informal payments, have frustrated the objectives of the FTA.

\subsection{Interpretation of Result on Monetary Policy for WAMZ}

Monetary policy between Ghana-Liberia, Guinea-Nigeria as well as Gambia-Liberia were insignificantly asymmetric with correlation coefficients of (-0.09), (-0.06) and (-0.05) respectively. However, apart from the correlation coefficient of monetary policy between Ghana-Nigeria that was highly symmetric with a value of (0.53), the rest of other pairs of countries all had insignificant coefficients. The reason advanced for this is that WAMZ region has multiple currencies and multiple central banks, hence, divergent monetary policies. The similarity targets of the convergence, growth and solidarity pact under enforcement is yet to propel WAMZ to the desired level of symmetry in monetary policy. This finding supports the view of Fiess (2005) that if shocks are predominantly country-specific, then the ability to conduct independent monetary and fiscal policy is usually seen as important in helping an economy adjust to a new equilibrium. 
4.4. Interpretation of Result on Fiscal Policy for WAMZ

Fiscal policies between pairs of countries within WAMZ were all insignificantly symmetric with correlation coefficient ranging between (0.01) to (0.41) except in the case of Guinea-Liberia and LiberiaNigeria with significant correlation coefficients of (0.47) and (0.67) respectively. The reason for this weak symmetry in fiscal policy within WAMZ may be as a result of the fact that the bulk of the revenue generated by individual countries might have been misappropriated, mismanaged or even channeled into foreign economies as a result of corruption. This finding also supports the view of Fiess (2005) that if shocks are predominantly country-specific, then the ability to conduct independent monetary and fiscal policy is usually seen as important in helping an economy adjust to a new equilibrium.

\subsection{Result of Pearson Correlation Analysis for West African Economic and Monetary Union (WAEMU)}

\begin{tabular}{|c|c|c|c|c|c|}
\hline \multirow{2}{*}{ Country pairs } & \multicolumn{4}{|c|}{ Variables } & \multirow{2}{*}{$\begin{array}{c}\text { Synchronization/ } \\
\text { Symmetry level }\end{array}$} \\
\hline & BS & TF & MP & FP & \\
\hline Benin-Burkina Faso & $0.817^{*}$ & $0.674^{*}$ & 0.399 & -0.227 & $++0 \mathrm{O}$ \\
\hline Benin-Cote d'Ivoire & $0.846^{*}$ & -0.243 & -0.305 & 0.381 & $+0 \mathrm{OO}$ \\
\hline Benin-Guinea Bissau & 0.256 & $0.563^{*}$ & 0.013 & -0.129 & $\mathrm{O}+\mathrm{OO}$ \\
\hline Benin-Mali & $0.816^{*}$ & $0.700^{*}$ & -0.157 & 0.209 & $++\mathrm{OO}$ \\
\hline Benin-Niger & $0.714 *$ & $0.843^{*}$ & 0.319 & $0.754 *$ & $++0+$ \\
\hline Benin-Senegal & $0.857 *$ & $0.859^{*}$ & 0.238 & -0.036 & ++00 \\
\hline Benin-Togo & $0.732^{*}$ & $0.864^{*}$ & 0.366 & $0.546^{*}$ & $++\mathrm{O}+$ \\
\hline Burkina Faso-Cote d'Ivoire & $0.772^{*}$ & $-0.484 * *$ & $-0.565^{*}$ & -0.285 & +--0 \\
\hline Burkina Faso-Guinea Bissau & 0.245 & 0.425 & $-0.581^{*}$ & 0.299 & $\mathrm{OO}-\mathrm{O}$ \\
\hline Burkina Faso-Mali & $0.680^{*}$ & $0.755^{*}$ & 0.114 & -0.335 & $++\mathrm{OO}$ \\
\hline Burkina Faso-Niger & $0.870^{*}$ & $0.734 *$ & 0.345 & -0.338 & ++00 \\
\hline Burkina Faso-Senegal & $0.790^{*}$ & $0.879^{*}$ & $0.730^{*}$ & -0.247 & +++0 \\
\hline Burkina Faso-Togo & $0.847 *$ & $0.775^{*}$ & 0.277 & $-0.496^{* *}$ & $++\mathrm{O}-$ \\
\hline Cote d'Ivoire-Guinea Bissau & -0.102 & -0.321 & $0.468^{* * *}$ & -0.139 & $\mathrm{OO}+\mathrm{O}$ \\
\hline Cote d'Ivoire-Mali & $0.841^{*}$ & $-0.566^{*}$ & 0.017 & 0.087 & +-00 \\
\hline Cote d'Ivoire-Niger & $0.826^{*}$ & $-0.582^{*}$ & -0.302 & 0.322 & +-00 \\
\hline Cote d'Ivoire-Senegal & $0.883^{*}$ & -0.445 & -0.355 & 0.250 & +000 \\
\hline Cote d'Ivoire-Togo & $0.892^{*}$ & $-0.519^{*}$ & 0.097 & $0.648 *$ & $+-\mathrm{O}+$ \\
\hline Guinea Bissau-Mali & 0.243 & $0.650^{*}$ & -0.223 & 0.135 & $\mathrm{O}+\mathrm{OO}$ \\
\hline Guinea Bissau-Niger & 0.227 & $0.583^{*}$ & -0.410 & 0.064 & $\mathrm{O}+\mathrm{OO}$ \\
\hline Guinea Bissau-Senegal & 0.228 & $0.593^{*}$ & -0.252 & $-0.722^{*}$ & $\mathrm{O}+\mathrm{O}-$ \\
\hline Guinea Bissau-Togo & 0.079 & $0.652 *$ & 0.188 & -0.421 & $\mathrm{O}+\mathrm{OO}$ \\
\hline Mali-Niger & $0.781 *$ & $0.838^{*}$ & 0.104 & 0.135 & $++\mathrm{OO}$ \\
\hline Mali-Senegal & $0.925^{*}$ & $0.845^{*}$ & -0.015 & -0.330 & $++\mathrm{OO}$ \\
\hline Mali-Togo & $0.818^{*}$ & $0.818^{*}$ & -0.265 & 0.033 & $++\mathrm{OO}$ \\
\hline Niger-Senegal & $0.855^{*}$ & $0.855^{*}$ & 0.015 & -0.160 & ++00 \\
\hline Niger-Togo & $0.939 *$ & $0.877^{*}$ & -0.046 & $0.484^{* * *}$ & $++\mathrm{O}+$ \\
\hline Senegal-Togo & $0.857 *$ & $0.903^{*}$ & $0.538^{* * *}$ & 0.448 & +++0 \\
\hline
\end{tabular}

Note: (+) synchronous/symmetric; (-) asynchronous/asymmetric; (0) insignificant; ( $\left.{ }^{*}\right) 1$ percent level of significance; (**) 5 percent level of significance; BS Business cycles; TF - Trade flows; MP - Monetary policy; FP - Fiscal policy

\subsection{Interpretation of the Result on Business Cycles for WAEMU}

As shown in Table 2 within the West African Economic and Monetary Union (WAEMU), it is indicative that Benin Republic was synchronous with Guinea-Bissau, Burkina Faso, Cote d'Ivoire, Mali, Niger, Senegal and Togo with correlation coefficient within the range of $(0.26)$ and (0.86) respectively. Burkina Faso was also synchronous with Guinea-Bissau, Cote d'Ivoire, Mali, Niger, Senegal and Togo within the range of (0.24) and (0.87) respectively. Cote d'Ivoire was strongly synchronous with Mali, Niger, Senegal and Togo within the range of (0.83) and (0.89) respectively, but asynchronous with Guinea-Bissau with a coefficient of (-0.10). Mali was synchronous with Guinea-Bissau, Niger, Senegal and Togo within the range of (0.24) and (0.93) respectively. Niger was also synchronous with Guinea-Bissau, Senegal and Togo within the range of (0.23) and (0.94) respectively. Also, Guinea-Bissau was weakly synchronous with Senegal and Togo with coefficients of (0.23) and (0.08) respectively, while Senegal was strongly synchronous with Togo with a coefficient of (0.86).

The reason why the level of WAEMU business cycle is that synchronous is because all the WAEMU countries, with the exception of Guinea-Bissau, share a common French heritage in their legal and administrative systems. In addition, they have maintained the common currency inherited at the time of independence, which is the CFA Franc. They have a common monetary policy, which is implemented by the 
common central bank, the Banque centrale des Etats de l'Afrique de l'Ouest (BCEAO). The French Treasury guarantees the convertibility of the common currency. Largely reflecting these commonalities, the WAEMU countries have been able to make more progress towards economic integration than the rest of ECOWAS. This supports the view of Artis and Zhang (1999) that increased monetary integration was positively related to business cycles synchronization.

\subsection{Interpretation of the Result on Trade Flows for WAEMU}

As shown in Table 2 trade flows were strongly symmetric between Benin Republic and Burkina Faso, Guinea-Bissau, Mali, Niger, Senegal and Togo with correlation coefficients ranging from (0.56) to (0.86), but Benin Republic had trade flows asymmetry of (-0.24) with Cote d'Ivoire. Trade flows was also strongly symmetric between Burkina Faso and Guinea-Bissau, Mali, Niger, Senegal and Togo, with correlation coefficients ranging between (0.43) and (0.88) respectively, but was asymmetric between Burkina Faso and Cote d'Ivoire with a coefficient of (-0.48). Between Cote d'Ivoire and Guinea Bissau, Mali, Niger, Senegal and Togo the flow of trade was asymmetric ranging from (-0.32) to (-0.58). It was also asymmetric between Togo and Guinea-Bissau with a coefficient of (-0.65), but between Guinea-Bissau and Mali, Niger and Senegal, the flow of trade was strongly symmetric within the range of (0.58) and (0.65) respectively. Also, trade flow was strongly symmetric between Mali and Niger, Senegal and Togo with coefficients ranging from (0.82) to (0.85). It was also strongly symmetric between Niger and Senegal, Niger and Togo and Senegal and Togo with coefficients of (0.86), (0.88) and (0.90) respectively.

It is evident that trade flows between Cote d'Ivoire and all other countries under WAEMU were all asymmetric. This is as a result of the fact that the total trade balance in goods and services within WAEMU reveals an overall deficit down to 2017 except in the case of Cote d'Ivoire with an overall surplus down to 2017. These regions are developing economies and are also import dependent. Their only source of export is raw materials which are exported to developed economies. This supports the findings of Mendoza (1991); Mendoza. (1995) that goods produced within by developing economies are not competitive enough to satisfy the needs of the region. Likewise, it corroborates the argument put forward by Chang (2011) that business cycle synchronization has not increased trade integration.

However, given that the level of trade flows within WAMZ is less symmetric than within WAEMU, the reason for this could be deduced from the fact that the currency within WAEMU region, the CFA Franc, is tied to the Euro and they already have an established monetary union whereas the reverse is the case in WAMZ with lots of disparities in currencies. WAEMU countries have, in the meantime, formed their own Customs Union, with the adoption of a CET in January 2000 and an Inter-State Road Transit Convention, which made possible the creation of a cross-border insurance system. WAEMU also achieved progress in the harmonization of domestic taxation with the VAT ranging from 18\%-20\% and excise duty. These achievements notwithstanding, the WAEMU Customs Union faces implementation challenges, with its member states failing to agree to the collection of the CET at the point of entry into the community, instead of each country doing so at its border. In order to boost intra-ECOWAS trade, NTBs hindering the free flow of goods should be removed, and negotiations on the CET should come to closure. In an effort to check these obstacles, a Regional Observatory of Bad Practices has recently been established. Above all these challenges, incentives through cyclical thrift schemes should be injected at proportional rate depending on the degree of preparedness of the domestic industries within the ECOWAS region to intensify production.

\subsubsection{Interpretation of Result on Monetary Policy for WAEMU}

As shown in Table 2 monetary policy was significantly asymmetric between Burkina Faso-Cote d'Ivoire and Burkina Faso-Guinea Bissau as pairs of countries under WAEMU with correlation coefficients of (-0.57) and (-0.58) respectively. However, between Burkina Faso-Senegal, Cote d'Ivoire-Guinea Bissau and SenegalTogo as pairs, their correlation coefficients were significantly symmetric with values of (0.73), (0.47) and (0.54) respectively. Aside from these, all other pairs of countries' coefficients were statistically insignificant. Despite the fact that these economies' currency, the CFA Franc is tied to the euro the level of disparities in monetary policy could be attributed to their differences in demographic, geographic and economic weights. Therefore, in line with Fiess (2005) if shocks are predominantly country-specific, then the ability to conduct independent monetary and fiscal policy is usually seen as important in helping an economy adjust to a new equilibrium.

\subsubsection{Interpretation of Result on Fiscal Policy for WAEMU}

As shown in Table 2 fiscal policy was significantly symmetric between Benin-Togo, Cote d'Ivoire-Togo and Niger-Togo as pairs of countries under WAEMU with correlation coefficients of (0.55), (0.65) and (0.48) respectively. Likewise, Benin-Niger was also significantly symmetric with a correlation coefficient of (0.75). Conversely, the fiscal policy of Burkina Faso-Togo and Guinea Bissau-Senegal as pairs were significantly asymmetric with correlation coefficients of (-0.50) and (-0.72) respectively. Aside from these, all other pairs of countries' coefficients were statistically insignificant. The reason for this disparity in symmetry and asymmetry in fiscal policy within WAEMU may be as a result of the fact that the bulk of the revenue generated by the individual countries might have been misappropriated, mismanaged or even channeled into foreign economies as a result of corruption. For WAEMU, given that their currency is tied to the euro makes 
the regulation of their budgets simpler. But on the whole, strategies must be put in place to check diversification of funds. Therefore, in line with Fiess (2005) if shocks are predominantly country-specific, then the ability to conduct independent monetary and fiscal policy is usually seen as important in helping an economy adjust to a new equilibrium.

\section{Summary of Findings}

The essence of this study was to examine trade flows, optimal macroeconomic policy and business cycles synchronization in West Africa. The Pearson correlation analysis provided evidence that the business cycles of nine (9) pairs of countries out of fifteen (15) were synchronized and out of the nine (9) pairs only four pairs, Ghana-Guinea, Ghana-Nigeria, Guinea-Gambia and Guinea-Nigeria were significantly synchronized. But in the case of WAEMU, out of the 28 pairs of countries, 21 pairs were significantly synchronized which comprise Benin-Burkina Faso, Benin-Cote d'Ivoire, Benin-Mali, Benin-Niger, Benin-Senegal, Benin-Togo, Burkina Faso-Cote d'Ivoire, Burkina Faso-Mali, Burkina Faso-Niger, Burkina Faso-Senegal, Burkina Faso-Togo, Cote d'Ivoire-Mali, Cote d'Ivoire-Niger, Cote d'Ivoire-Senegal, Cote d'Ivoire-Togo, Mali-Niger, Mali-Senegal, Mali-Togo, Niger-Senegal, Niger-Togo and Senegal-Togo.

On the level of symmetry in trade flows, the Pearson correlation analysis revealed that 9 pairs of countries under WAMZ were significantly symmetric and these were Ghana-Guinea, Ghana-Gambia, Ghana-Liberia, Ghana-Sierra Leone, Guinea-Liberia, Guinea-Sierra Leone, Gambia-Liberia, Gambia-Sierra Leone and LiberiaSierra Leone. But within the WAEMU region, 20 pairs were significantly symmetric. These include BeninBurkina Faso, Benin-Guinea Bissau, Benin-Mali, Benin-Niger, Benin-Senegal, Benin-Togo, Burkina FasoMali, Burkina Faso-Niger, Burkina Faso-Senegal, Burkina Faso-Togo, Guinea Bissau-Mali, Guinea BissauNiger, Guinea Bissau-Senegal, Guinea Bissau-Togo, Mali-Niger, Mali-Senegal, Mali-Togo, Niger-Senegal, Niger-Togo, and Senegal-Togo.

On the level of symmetry in monetary policy, the Pearson correlation analysis showed that under WAMZ, only Ghana-Nigeria as a pair was significantly symmetric. But within the WAEMU region only Burkina Faso-Senegal, Cote d'Ivoire-Guinea Bissau, and Senegal-Togo as pairs were significantly symmetric.

On the level of symmetry in fiscal policy, the Pearson correlation analysis revealed that under WAMZ, only Guinea-Liberia, and Liberia-Nigeria as pairs were significantly symmetric. Meanwhile, within the WAEMU region, only Benin-Niger, Benin-Togo, Cote d'Ivoire-Togo, and Niger-Togo were significantly symmetric.

\section{Conclusion}

This work provides an answer on the feasibility of creating a second West African monetary union. It is quite glaring from the foregoing analysis that WAEMU that was established in the year 1994 does not seem to be thriving exceedingly better than WAMZ. Their flow of trade is more with other nations outside Africa and does not in entirety synchronize their business cycles. The circumstance on which WAEMU was founded via colonization has made it heavily dependent on the conditionality of her founding father, France. The case of WAMZ on the contrary can never be the same because their decisions to thrive must solely be based on their perceptions, observations, investigations, findings and thus, the relevance of this research. There is a clear-cut indication that most countries within WAMZ are still far from being merged to form a monetary union. The few with the level of symmetry in trade flows, monetary and fiscal policies that could eventually synchronize regional business cycles comprise of Ghana, Nigeria, Gambia and Guinea.

\section{Policy Recommendations}

From the findings the following policy recommendations are put forward:

i. Pairs of countries that are highly symmetric under WAMZ such as Nigeria, Ghana, Gambia and Guinea should form the Second West African Monetary Union (SWAMU) by the year 2021 and create room for others readily available to eventually merge-up.

ii. The Nigerian naira, Ghanaian cedi, Gambian dalasi and the Guinean franc should continue to thrive but multilaterally tied/pegged to a single currency the wamz-eco while paving ways for the individual currencies to eventually culminate.

iii. Countries that are strongly symmetric under WAEMU such as Burkina Faso-Mali, Cote d'IvoireGuinea Bissau, Cote d'Ivoire-Mali, Cote d'Ivoire-Senegal, Cote d'Ivoire-Togo, Guinea BissauMali, as well as Guinea Bissau-Senegal should unilaterally realign its exchange rate, while countries without strong similarity ties should disengage from WAEMU and operate independently, partaking in the cyclical thrift scheme to boost industrialization in preparation to re-merge in due course.

iv. Trade barriers should to a large extent be relaxed and trade protection/restriction emphasized amongst countries within West Africa. Countries must trade intensely with each other excepts where the goods and services are lacking. 


\section{References}

AFDB. (2018). African development bank (AFDB) socioeconomic data base, 1960-2021. Retrieved from: https://dataportal.opendataforafrica.org/nbyenxf/afdb-socio-economic-database-1960-202 1.

Akin, C. (2006). Multiple determinants of business cycle synchronization. Paper presented at the Paper Presented at the 2006 Annual Meeting of the Canadian Economic Association, Montreal.

Artis, M. J., \& Zhang, W. (1999). Further evidence on the international business cycle and the ERM: Is there a European business cycle? Oxford Economic Papers, 51(1), 120-132.Available at: https://doi.org/10.1093/oep/51.1.120.

Baldwin, R., \& Wyplosz, C. (2009). The economics of European integration (3rd ed., pp. 314-349). London: McGraw Hill Higher Education.

Baxter, M., \& King, R. G. (1999). Measuring business cycles: Approximate band-pass filters for economic time series. Review of Economics and Statistics, 81(4), 575-593.

Baxter., M., \& Kouparitsas, M. A. (2005). Determinants of business cycle comovement: A robust analysis. Journal of Monetary Economics, 52(1), 113-157.

Bordo, M. D., \& Helbling, T. (2003). Have national business cycles become more synchronized? NBER Working Paper, No 10130.

Böwer, U., \& Guillemineau, C. (2006). Determinants of business cycle synchronization across euro area countries. ECB Working Paper Series, 587.

Burns, A. M., \& Mitchell, W. C. (1946). Measuring business cycles (Vol. 2). National Bureau of Economic Research: New York.

Calderón, C., Chong, A., \& Stein, E. (2002). Trade intensity and business cycle synchronization: Are developing countries any different? Working Papers of the Central Bank of Chile, No. 195, 1-39.

Chang, H. (2011). Macroeconomic synchronization and policy coordination after regional economic integration in the Americas. IdeAs, 1, 1-2 1.

Cohen, B. J. (1992). The new palgrave dictionary of money and Finance. London: The Macmillan Press Limited.

Coleman, S. (2011). Investigating business cycle synchronization in West Africa. Discussion Papers in Economics. No. $2011 / 1,1-21$.

Crespo-Cuaresma, J., Pfaffermayr, M., Fernández-Amador, O., \& Keppel, C. (2010). Macroeconomic aspects of European integration: Fiscal policy, trade integration and European business cycle. FIW-Research Report, No. 04,1-35.

Darvas, Z., \& Szapáry, G. (2004). Business cycle synchronization in the enlarged EU: comovements in the new and old members. Central Bank of Hungary Working Paper, No. 2004/1.

De Haan, J., Inklaar, R., \& Jong-A-Pin, R. (2005). Will business cycles in the Euro Area converge? A critical survey of empirical research. CCSO Working Paper, 2005/08.

Fidrmuc, J. (2001). The endogeneity of the optimum currency area criteria, intraindustry trade, and EMU enlargement. Paper presented at the LICOS Discussion Paper, Centre for Transition Economics.

Fiess, N. (2005). Business cycle synchronization and regional integration: A case study of Central America. World Bank Policy Research Working Paper, No. 3584,1-19.

Frankel, J. A., \& Rose, A. K. (1998). The endogeneity of the optimum currency area criteria. Economic Journal, 108(449), 1009-1025.

Franken., H., Fort, G. L., \& Parrado, E. (2011). Business cycle responses and the resilience of the chilean economy. Paper presented at the In P. Barrientos, Theory, History and Evidence of Economic Convergence in Latin America, 2007.

Gomez, V., \& Maravall, A. (1996). Programs TRAMO and SEATS. Instructions for the User (with some updates). Working Paper No. 9628, Research Department, Bank of Spain.

Grigoli, F. (2011). The impact of trade integration on business cycle synchronization for Mercosur Countries. Liuc Papers, No. 222 .

Jidoud, A. (2012). The sources of macroeconomic fluctuations in Sub-Saharan African Economies: An application to Cote d'Ivoire. TSE Working Papers 12-346, Toulouse School of Economics (TSE). Retrieved from: https://ideas.repec.org/p/tse/wpaper/26459.html.

Jules-Armand, T. (2007). Bilateral trade and business cycles synchronization: African monetary integration perspective. Economic Bulletin, 6(25), 1-15.

Juvenal, L., \& Monteiro, P. S. (2012). Trade and synchronization in a multi-country economy. Working Paper, No 1-48 Research Division, Federal Reserve Bank of St. Louis.

Kappel, S. (2015). A comparison of business cycles synchronization in the Euro Area and some potential monetary unions. Applications of Agriculture and Silviculturae Mendelianae Brno, 63(4), 1277-1285.

Kenen, P. (1969). The theory of optimum currency areas: An eclectic view. In Robert Mundell and Alexander Swoboda (Eds.), Monetary Problems of the International Economy (pp. 41-60). Chicago: University of Chicago Press.

Kose, M. A., Prasad, E. S., \& Terrones, M. E. (2003). How does globalization affect the synchronization of business cycles? American Economic Reviere, 93(2), 57-62.Available at: https://doi.org/10.1257/000282803321946804.

Krugman, P. (1993). Lessons of Massachusetts for EMU. In F. Torres \& F. Giavazzi (Eds.), Adjustment and Growth in the European Monetary Union (pp. 241-261). New York: Cambridge University Press and CEPR.

Kumakura, M. (2005). Trade and business cycle correlations in Asia-Pacific. Institute of Developing Economies (IDE) Discussion Paper No. 44.

Maruping, M. (2005). Challenges for regional integration in Sub-Saharan Africa: Macroeconomic convergence and monetary coordination. In Africa in the World Economy - the National. Fondad, The Hague: Regional and International Challenges.

McKinnon, R. I. (1963). Optimum currency areas. The American Economic Review, 53(4), 717-725.

Mendoza, E. G. (1991). Real business cycles in a small open economy. The American Economic Revierw, 81(4), 797-818.

Mendoza., E. G. (1995). The terms of trade, the real exchange rate, and economic fluctuations. International Economic Review, 36(1), 101-137.Available at: https://doi.org/10.2307/2527429.

Mundell, R. A. (1961). A theory of optimum currency areas. The American Economic Review, 51(4), 657-665. 
Nzimande, N. P., \& Ngalawa, H. (2017). The endogeneity of business cycle synchronization in SADC: A GMM approach. Cogent Economics and Finance, 5, 1358914.Available at: https://doi.org/10.1080/23322039.2017.1358914.

Pundit, M. (2011). Comovement of business cycles and trade in intermediate goods, job market paper. Chestnut Hill: Boston College.

Rana, P. B. (2007a). Economic integration and synchronization of business cycles in East Asia. Journal of Asian Economics, $18(5), 711-725$.

Rana., P. B. (2007b). Trade intensity and business cycle synchronization: The case of East Asia. Working Paper Series on Regional Economic Integration, No. 10, 1-20.

Sanusi, J. (2003). Ongoing efforts towards a monetary union in the West African sub-region. African Economic Review, 6(1), $1-4$.

Shin, K., \& Wang, Y. (2004). Trade integration and business cycle synchronization in East Asia. Asian Economic Papers, $2(3), 1-20$.

Tarawalie, A., Ahortor, C., Adenekan, A., \& Conte10, M. (2012). Political business cycles and macroeconomic convergence in the WAMZ: The case of Ghana and Nigeria. Journal of Monetary and Economic Integration, 11 (1), 59-94.

UNCTADstat. (2018). United nation conference on trade and development statistics. Retrieved from: https://unctadstat.unctad.org/EN/.

World Bank. (2018). World development indicators: Statistic department. Washington, DC 20433 USA: Publications Services. 